\title{
The Effects of Overprotective Parenting on Academic Self- esteem: The Moderating Role of Teachers
}

Brittany R. Valdez

Follow this and additional works at: https://researchrepository.wvu.edu/etd

\section{Recommended Citation}

Valdez, Brittany R., "The Effects of Overprotective Parenting on Academic Self-esteem: The Moderating Role of Teachers" (2016). Graduate Theses, Dissertations, and Problem Reports. 6858.

https://researchrepository.wvu.edu/etd/6858

This Thesis is protected by copyright and/or related rights. It has been brought to you by the The Research Repository @ WVU with permission from the rights-holder(s). You are free to use this Thesis in any way that is permitted by the copyright and related rights legislation that applies to your use. For other uses you must obtain permission from the rights-holder(s) directly, unless additional rights are indicated by a Creative Commons license in the record and/ or on the work itself. This Thesis has been accepted for inclusion in WVU Graduate Theses, Dissertations, and Problem Reports collection by an authorized administrator of The Research Repository @ WVU. For more information, please contact researchrepository@mail.wvu.edu. 


\title{
The Effects of Overprotective Parenting on Academic Self-esteem: The Moderating Role of Teachers
}

\author{
Brittany R. Valdez \\ Thesis submitted \\ to the College of Education and Human Services \\ at West Virginia University \\ in partial fulfillment of the requirements for the degree of \\ Master of Arts in \\ Educational Psychology with an emphasis in Child Development and Family Studies
}

Amy E. Root, Ph. D., Chair

Barbara Warash, Ed.D.

Melissa Sherfinski, Ph.D.

Department of Learning Sciences and Human Development

Morgantown, West Virginia

2016

Keywords: parental overprotection, teacher closeness

Copyright 2016 Brittany Valdez 


\title{
ABSTRACT \\ The Effects of Overprotective Parenting on Academic Self-esteem: The Moderating Role of Teachers
}

\begin{abstract}
Brittany R. Valdez
Overprotective parenting, or "helicopter parenting" as it is known in the media, is characterized by high levels of behavioral and psychological control, and has been found by previous empirical studies to be linked to several maladaptive child outcomes (Wood, McLeod, Sigman, Hwang, \& Chu, 2003). These outcomes include increased levels of anxiety, depression (Bayer, Sanson, \& Hemphill, 2006; LeMoyne \& Buchanan, 2011; Schiffrin, Liss, MilesMcLean, Geary, \& Erchull 2013), and shyness (Bayer, et al., 2006; Rubin, Coplan, \& Bowker, 2009) as well as decreased academic outcomes (Bernstein \& Triger, 2010; Padilla-Walker \& Nelson, 2012). However, much of the research regarding parental overprotection and academic outcomes has focused on older children (Padilla-Walker \& Nelson, 2012; Cutrona, Cole, Colangelo, Assouline, \& Russell, 1994). For this reason, the current study investigated the effects of parental overprotection on preschool aged children's academic self-esteem. The current study also investigated teacher-child relationships. Specifically, the effects of teacher closeness on children's academic self-esteem were examined. Previous empirical studies have found that positive teacher-child relationships have positive academic outcomes (Rudasill \& Rimm-Kaufman, 2009; Birch \& Ladd, 1997). The interaction between parental overprotection and teacher closeness was also examined in relation to children's academic self-esteem. This was done in order to investigate whether close teacher-child relationships moderate the effects of overprotective parenting on academic outcomes. The results revealed that parental overprotection was negatively associated with children's academic self-esteem. Teacher closeness was positively associated with children's academic self-esteem. Finally, no significant relationship between the interaction of parental overprotection and teacher closeness and children's academic self-esteem was found.
\end{abstract}


Statement of the Problem

Review of Literature

Statement of the Hypotheses

Method

Results

Discussion 
List of Tables

Table Page

1. Correlations and Descriptive Statistics of Parental Overprotection, Teacher 52 Closeness Aggregate, and Child Academic Self-esteem

2. Regression Analysis Summary for Parental Overprotection, Teacher Closeness Aggregate, and Child Academic Self-esteem 


\section{Overview}

Overprotective parenting, which incorporates high levels of behavioral and psychological control, has been linked to several maladaptive child outcomes (Wood, McLeod, Sigman, Hwang, \& Chu, 2003). These maladaptive outcomes in children include increased anxiety, depression (Bayer, Sanson, \& Hemphill, 2006; LeMoyne \& Buchanan, 2011; Schiffrin, Liss,

Miles-McLean, Geary, \& Erchull 2013), and shyness (Rubin, Coplan, \& Bowker, 2009; Bayer, et al., 2006). Some studies that have examined parental overprotection in relation to students' grade point averages (GPA) suggest that parental overprotection is also associated with decreased academic achievement (Bernstein \& Triger, 2010; Padilla-Walker \& Nelson, 2012). However, there is evidence that suggests that positive teacher-child relationships may moderate these effects, especially those directly related to the educational setting.

\section{Justification of Study}

While there is a long history of examining parental overprotection in the field of developmental psychology and human development (e.g., the work of Kenneth Rubin, Paul Hastings, Ronald Rapee, and others), little research has been conducted to examine how parental overprotection affects academic outcomes in young children. However, some studies have investigated the relationship between parental overprotection and academic outcomes in older children. For example, Cutrona, Cole, Colangelo, Assouline, and Russell (1994) found that college students with overprotective parents had lower GPAs than their peers. Based on evidence suggesting that parental overprotection has a negative impact on academic outcomes in older children (Padilla-Walker \& Nelson, 2012; Cutrona et al., 1994) and that this parenting style is associated with other negative outcomes, such as increased anxiety, depression (Bayer et al., 2006; LeMoyne \& Buchanan, 2011; Schiffrin, Liss, Miles-McLean, Geary, \& Erchull 2013), and 
shyness (Rubin, Coplan, \& Bowker, 2009; Bayer et al., 2006) in preschool-aged children, it is reasonable to hypothesize that preschool aged children's academic outcomes may also suffer as a result of this parenting style.

When examining academic outcomes, it is important to consider the implications of teacher effects on children's outcomes. Teacher-child relationships are generally considered positive when teachers display positive affect and are sensitive to children's needs (Buyse, Verschueren, \& Doumen, 2011). These types of teacher-child relationships are associated with positive child outcomes, such as good school work habits (Rudasill \& Rimm-Kaufman, 2009) and autonomy development (Birch \& Ladd, 1997). Rudasill and Rimm-Kaufman (2009) noted that children who establish positive teacher-child relationships perform better academically. Buhs, Rudasill, Kalutskaya, and Griese (2015) also reported that sensitive teaching can moderate the association between shyness in children and poor academic outcomes. Because teacher-child relationships are so salient in the literature, it seems reasonable that teacher-child relations may be especially important for children who are at an increased risk for developing negative outcomes as a result of experiencing overprotective parenting practices in the home. Thus, it stands to reason that close relationships with teachers may moderate the hypothesized negative effects of parental overprotection on children's academic outcomes.

\section{Statement of the Problem}

While the effects of parental overprotection have been examined in young children, much of the previous research has focused on internalizing problems (Bayer et al., 2006; LeMoyne \& Buchanan, 2011; Rubin et al., 2009; Schiffrin et al., 2013). Less research has been done in regards to the academic setting. However, there is a fair amount of research suggesting that 
parental overprotection can impact academic outcomes in older populations of children (Cutrona et al., 1994; Padilla-Walker \& Nelson, 2012). Thus, this area of research is relatively novel. In addition, there is limited research regarding positive teacher-child relationships as a moderator on the association between overprotective parenting and children's academic outcomes. Understanding how teachers contribute to this process could also provide a better understanding of the multiple influences on a child's development.

\section{Purpose of the Study}

The purpose of this study is to investigate how parental overprotection affects academic self-esteem in preschool aged children. Studying these relationships will add to the body of existing research in this area. Additionally, this study will investigate how establishing close relationships with teachers affects academic self-esteem in the same population. Finally, positive teacher-child relationships, termed in this study as "teacher closeness," will be examined as a moderator in the relationship between parental overprotection and academic self-esteem. 


\section{Literature Review}

Parenting styles have been studied in relation to various child outcomes in the field of developmental psychology and human development. Parenting styles can be defined as parental attitudes and behaviors that are communicated to children (Williams et al., 2009). How parents respond to and interact with their children affects the emotional climate of the parent-child relationship (Williams et al., 2009). While research investigating parenting styles is not new, interest in overprotective parenting has grown over the past several decades. This is largely due to the recent increase in discussing "helicopter parents," which is a mainstream term for overprotective parenting, in popular culture and media. Overprotective parents can be described as parents who are excessively involved in their children's lives (Bernstein \& Trigger, 2010).

While much of the mainstream focus on overprotective parenting centers on older children, there is a long history of examining young children of overinvolved parents in the field of developmental psychology and human development (e.g., the work of Kenneth Rubin, Paul Hastings, Ronald Rapee, and others). The interest in overprotective parenting also extends beyond developmental psychology. For instance, in an issue of UC Davis Law Review, Bernstein and Trigger (2010) discuss this parenting style and note that parental overprotection often begins very early in a child's life, sometimes even before the child is born. Bernstein and Trigger (2010) assert that overprotective parents often begin their invasive parenting practices by obsessively reading child development books and online forums in expectation of their children's births. Overprotective parents continue to exert their control by being overly strict about areas, such as academics, extracurricular activities, and friendships, as children age (Bernstein \& Trigger, 2010). Importantly, these parents engage in this behavior because they believe that parental overprotection will ultimately benefit their children (Bernstein \& Trigger, 2010). Moreover, this 
behavior in the context of middle-class, North American culture is inappropriate, but may be appropriate in high risk, dangerous environments (e.g., Jackson, 1993). As stated by LeMoyne and Buchanan (2011), overprotective parents utilize appropriate parenting strategies but take them to an inappropriate degree. This means that many of the parenting strategies utilized by overprotective parents, such as behavioral control, can be beneficial to children when used in moderation. However, these parents utilize these strategies to excessive degrees, which often results in negative outcomes for children. This over-involvement may be aided by modern technology, such as cell phones, that allows overprotective parents to maintain control of their children even when they are not at home (Bernstein \& Trigger, 2010).

In addition to increased access to modern technology, other contextual issues may prompt some parents to engage in overprotective strategies. Senior (2014) noted that the social context for having children has changed over the past century. Previous generations viewed children as helpers in accomplishing household chores, and most children stayed at home instead of attending school to assist their parents as needed (Senior, 2014). Societal views have now shifted, and an emphasis has been placed on formal schooling (Senior, 2014). Children no longer spend their days assisting their parents with work and chores; instead, parents spend time cultivating children and preparing them for school (Senior, 2014). This may have caused parents to feel societal pressure to adequately prepare their young children for learning.

There is evidence that parents in middle and upper class families experience the most pressure to prepare their children for school. In fact, Senior (2014) reported that middle and upper class mothers who graduated from college spent an average of five hours per week engaging their children in learning activities, while lower class mothers who did not graduate from high school spent an average of only two hours per week engaging their children in 
learning activities. Not only do parents now spend a significant amount of time trying to prepare their children for school, but they also spend more time with their children in total than previous generations. Milkie, Mattingly, Nomaguchi, Bianchi, and Robinson (2004) found that modern parents spend more time with their children than parents did in 1975 (Senior, 2014). Despite this additional time, Milkie et al. (2004) also reported that $85 \%$ of modern parents believe that they do not spend enough time with their children (Senior, 2014). This constant striving for perfect parenting likely leads parents to engage in overprotective parenting behaviors.

The pressure to prepare children for school at young ages might also be resultant of a recent focus on academic standards within school systems. For example, early education in West Virginia focuses on six areas of learning standards (West Virginia Department of Education, 2013). These areas are social and emotional development, language and literacy, mathematics, science, the arts, and physical health (West Virginia Department of Education, 2013). With this recent push toward formal learning at young ages, many opportunities for children to engage in play in school settings have been replaced with more stringent methods of learning, such as memorization (Warash, Root, \& Doris, 2016). This trend has been seen in preschools as well as elementary and secondary schools (Warash et al., 2016).

There is evidence that parents have adopted this strict view of learning. According to Brantlinger (2003), highly educated parents from middle and upper class families often report that they understand the importance of play and prefer progressive education; however, when faced with real-life choices, they are more likely to select curriculums that prepare their children to be college-bound over more progressive curriculums. These findings suggest that even though highly educated parents understand which activities are developmentally appropriate for their young children, they are still highly concerned with formal learning and preparation for college. 
In addition, a study by Belfield and Garica (2014) reported that from 1993 to 2007, parents have increased their expectations for children's development of school readiness skills (Warash et al., 2016). Another study by Shine and Acosta (2000) found that parents spent more time formally instructing and teaching their children than they did engaging in pretend play when in a museum even though the museum exhibits were designed to promote play (Warash et al., 2016). This suggests that parents now believe that formal instruction rather than play is more beneficial to children's academic outcomes, and therefore, spend less time playing and more time teaching. However, this shift to less play and more formal methods of teaching and learning may be misguided since pretend play is developmentally appropriate and an important activity for preschool aged children (Bredekamp, 2004). Pretend play has been found to promote behaviors, such as problem-solving and executive functioning, that allow children to be successful in school and social relationships later in life (Bredekamp, 2004). Since overprotective parents are usually concerned with preparing their children to perform well academically, it is likely that they are restricting pretend play and instead engaging in more formal teaching activities, which may adversely affect their children's academic outcomes (Lareau, 2011).

It is important to note that academic standards in preschool differ from academic standards in elementary school, secondary school, and college. Academic achievement is, in general, the variable that is studied in populations of older children to gauge academic outcomes. Academic achievement is usually measured by grade point averages (GPA) or standardized tests (Marsh \& O’Mara, 2008). For example, academic achievement assessed using GPA was the primary variable examined by Cutrona, Cole, Colangelo, Assouline, and Russell (1994) in their sample of college students with overprotective parents. However, this variable is not applicable to preschool aged children (ages 3-5) because they do not receive formal grades or take 
standardized tests. Instead, jargon associated with academic outcomes for preschool aged children generally focuses on cognitive and socioemotional development, such as reflected in the West Virginia Department of Education's six areas of learning standards (West Virginia Department of Education, 2013). Since measures of academic achievement are not applicable to preschool aged children, the current study will instead investigate children's academic selfesteem. Academic self-esteem can be defined as attitudes and perceptions about one's academic performance (Marsh \& O’Mara, 2008). Although academic self-esteem and academic achievement are distinct constructs, several longitudinal studies have shown that they are mutually reinforcing (Marsh \& O’Mara, 2008). In fact, a study by Pallas, Entwisle, Alexander, and Cadigan (1987) reported that children's academic self-esteem in first grade was positively related to their academic achievement later in the school year. Thus, academic self-esteem should reflect academic achievement for the purposes of this study.

\section{Theoretical Basis}

The study of parental overprotection can best be understood via the lens of attachment theory (Bowlby, 1977). Parent-child attachment was described by Ainsworth and Bell (1970) as an affectional tie that is established between a parent and an infant. There are three main types of parent-child attachment styles. The types of attachment are secure, anxious, and avoidant.

Secure parent-child attachment occurs when children feel safe and comforted by their parents (Bowlby, 1977). When children feel safe and comforted, they use their parents as secure bases for exploration (Ainsworth \& Bell, 1970). Secure attachment is regarded as the most optimal form of parent-child attachment. In fact, most children who establish secure attachment 
relationships with their parents tend to grow up to be self-reliant and have high self-esteem (Bowlby, 1977).

If children do not form secure attachment relationships with their parents, they are classified as insecurely attached. Insecure attachment can indicate either anxious or avoidant attachment relationships. Anxious attachment is thought to be the result of having inconsistent and unreliable parents (Bowlby, 1977). Children who form anxious attachment relationships with their parents typically display large amounts of stress in the absence of their parents (Bowlby, 1977). Avoidant attachment is believed to be the result of inattentive or abusive parenting (Bowlby, 1977). This often leads to children experiencing difficulty trusting others and establishing close relationships later in life (Simpson, 1990).

\section{Links between Attachment and Parenting Styles}

Due to the fact that parenting practices influence the emotional climate of the parentchild relationship (Williams et al., 2009), attachment styles are closely related to parenting practices. Empirical evidence generally supports the notion that parents who are warm and supportive during interactions with their children foster the development of secure parent-child attachment relationships. This is because warm, supportive parenting practices make children feel safe and comfortable with using their parents as secure bases for exploration (Bayer, Sanson, \& Hemphill, 2006). In fact, a study by Barnett, Kidwell, and Leung (1998) found that children who had parents who used warm and supportive parenting practices were more likely to establish secure attachment relationships with their parents than were children who had parents who were not warm and supportive during parent-child interactions. Conversely, parenting practices that are inappropriately warm, such as overprotective parenting, often discourage children from 
feeling safe and comfortable in using their parents as secure bases for exploration (Bayer et al., 2006). Therefore, these children are less likely to establish secure attachment relationships with their parents.

Specific links between parenting practices and attachment have also been found in empirical studies. In a study examining the associations between parenting styles and parentchild attachment relationships, researchers found that authoritative parenting, which is characterized by parental warmth and support, predicted secure attachment (Karavasilis, Doyle, \& Markiewicz, 2003). Similarly, Barnett et al. (1998) found that parents of securely attached children were rated as significantly more warm and accepting and less controlling with their children than were parents of insecurely attached preschoolers.

\section{Parental Overprotection}

Recently, overprotective parenting has begun to be examined in relation to parent-child attachment and other child outcomes. Wood, McLeod, Sigman, Hwang, and Chu (2003) described overprotective parenting as autocratic parental decision making. According to Hastings, Nuselovici, Rubin, and Cheah (2010) parental overprotection involves the overexertion of control even when children are not in need of parental assistance or comforting. When parents engage in these behaviors, they undermine their children's autonomy, or selfdirecting independence (Chickering, 1969). By engaging in such parenting practices, these parents deny children opportunities to practice coping with developmentally normative challenges and often causes children to believe that they are incapable of independently completing tasks (Hastings et al., 2010). Thus, parental overprotection can be detrimental to child development. 
While overprotective parenting is characterized by excessive and unwarranted parental control, it is important to note that overprotective parenting is comprised of two distinctive types of parental control. These two types of parental control are behavioral control and psychological control. These constructs are complex. The appropriateness of using behavioral control and psychological control varies from child to child and by age (Barber, Olsen, \& Shagle, 1994). Therefore, some children inherently thrive from more parental control than others. Also, young children generally need more parental control than older children (Barber et al., 1994).

\section{Behavioral Control}

Behavioral control can be defined as excessive and developmentally inappropriate parental control over children’s behaviors and attitudes (Padilla-Walker \& Nelson, 2012). Although young children need some level of parental behavioral control, excessive amounts can have negative outcomes. For example, Baumrind (1966) reported that children aged 3 to 4 years who had mothers who self-reported exerting high levels of behavioral control were more likely to be insecurely attached to their mothers than peers whose mothers self-reported exerting lower levels of behavioral control. In addition, these children were also more likely than peers whose mothers did not use excessive behavioral control to be shy around peers and hostile when under stress (Baumrind, 1966).

\section{Psychological Control}

As for psychological control, Padilla-Walker and Nelson (2012) defined this construct as parental behaviors that are controlling and manipulative of children's emotions. Example behaviors include love withdrawal and guilt induction (Padilla-Walker \& Nelson, 2012). Psychological control has been linked with both externalizing and internalizing symptoms in preschool aged children (Barber, Olsen, \& Shagle, 1994). A study by Rubin, Coplan, Nelson, 
Cheah, and Lagace-Seguin (1997) used structural equation modeling to show how mothers' use of psychological control affected teachers' ratings of children's externalizing and internalizing behaviors. Significant associations between high use of maternal psychological control and children's externalizing behaviors, such as displays of aggression toward peers, and internalizing behaviors, such as displays of unhappiness and loneliness, were found. In addition, a study by Bayer et al. (2006), followed a sample of 2 year old children $(N=112)$ longitudinally for four years to examine predictors of early childhood internalizing problems. The results revealed that excessive parental psychological control was linked with anxiety and depression in young children (Bayer et al., 2006).

Additionally, several researchers have also noted the association between parental use of excessive psychological control and social withdrawal. In a study on children in elementary school, Mills and Rubin (1998) found that mothers who used excessive levels of psychological control were more likely to have withdrawn children. Rubin, Burgess, and Hastings (2002) also found that maternal use of psychological control can exacerbate social withdrawal in preschool aged children who displayed shy behaviors as toddlers. Thus, the use of psychological control may be particularly damaging for children who are predisposed to shyness. With regard to school, this can make attaining academic success difficult because attending school can be extremely stressful for shy children (Rubin et al., 2002). This means that shy children are likely to miss out on learning opportunities. Empirical evidence has also shown that teachers perceive shy children as less academically competent than peers who are not shy (Coplan, GavinskiMolina, Lagace-Seguin, \& Wichmann, 2001; Lloyd \& Howe, 2003; Rubin et al., 2009). This may be particularly detrimental to children during the preschool years since they learn by doing 
and interacting with others (Rubin et al., 2009). Thus, if shy children do not participate in these activities, their learning may be hindered.

\section{Effects on Academic Achievement}

Children who have overprotective parents are unlikely to properly develop the skills necessary for academic achievement, such as time management and the ability to strategize (Bernstein \& Triger, 2010). This is likely associated with these children being prevented from making developmentally-appropriate gains in autonomy (Bernstein \& Triger, 2010). Most empirical evidence regarding the effects of parental overprotection on academic outcomes have been conducted with older populations of children. For example, Padilla-Walker and Nelson (2012) found that college students with overprotective parents were less likely to be engaged in school. These students are also less likely to take a proactive approach to pursuing an education (Cutrona, Cole, Colangelo, Assouline, \& Russell, 1994). College students with overprotective parents have also been found to have lower GPAs than their counterparts (Cutrona et al., 1994). Despite these results, studies that have been conducted with younger populations of children have reported inconsistent results. A study by Jeynes (2003) found that increased parental involvement positively affected academic achievement in minority children. Another study conducted by Bethke (2011) found that high levels of parental involvement made positive differences in personal and academic growth in children. However, these studies examined parental involvement rather than parental overprotection. Therefore, further investigations are required to understand how parental overprotection affects academic outcomes in young children. Given that overprotective parenting has been found to be associated with other negative outcomes in early childhood, such as anxiety, depression (Bayer et al., 2006; LeMoyne \& Buchanan, 2011; Schiffrin, Liss, Miles-McLean, Geary, \& Erchull 2013), and shyness (Rubin, 
Coplan, \& Bowker, 2009; Bayer et al., 2006), it is reasonable to hypothesize that academic outcomes may also suffer as a result of this parenting style. Understanding this relationship may aid in developing effective strategies for appropriately engaging parents in their children's learning process.

\section{Impact of Teachers on Children's Adjustment}

While parenting styles influence children's adjustment, teacher-child relationships also have an impact. The teacher-child relationship affects how children perform both academically and socially in school (Rudasill \& Rimm-Kaufman, 2009). Previous research has shown that positive relationships with teachers can act as support networks for children. Researchers have also found that positive teacher-child relationships predicted both good work habits and fewer internalizing and externalizing problems in later school years (Rudasill \& Rimm-Kaufman, 2009).

Of importance to the current study, positive teacher-child relationships can occur even when parent-child relationships are subpar. According to Buyse, Verschueren, and Doumen (2011), children with insecure parent-child attachment relationships can still form close relationships with their teachers when teachers are warm and supportive. This means that children whose parents use parenting styles that are not conducive to fostering secure attachment relationships, such as those who engage in parental overprotection, can still form close relationships with teachers. Close relationships with teachers may help to shield these children from the negative effects associated with the parenting style employed in the home.

Teacher sensitivity plays a large role in whether or not positive teacher-child relationships are established. Sensitive behavior is characterized by warm and nurturing teacher- 
child interactions (Rimm-Kaufman et al., 2002). A study by Birch and Ladd (1997), which used a sample of 206 children with a mean age of 5.58, found that teachers who were warm and responsive in interactions with children encouraged autonomy development in the classroom. Since overprotective parents limit developmentally appropriate autonomy development (Hastings et al., 2010), having a teacher who supports autonomy growth may be especially beneficial to children who experience parental overprotection. Another study by O'Connor and McCartney (2007) found that close teacher-child relationships from preschool through third grade promoted children's academic achievement in third grade (Rudasill \& Rimm-Kaufman, 2009). These findings suggest that having high quality teacher-child relationships early on in the educational process is beneficial. Conversely, when teacher-child relationships are not positive, children are likely to struggle academically (Rudasill \& Rimm-Kaufman, 2009).

Previous research has also suggested that highly sensitive teachers may moderate the association between shyness and academic outcomes (Buhs, Rudasill, Kalutskaya, \& Griese, 2015). In a study focusing on preschool aged children through first grade, teacher sensitivity was found to be positively related to classroom engagement (Buhs et al., 2015). Additionally, researchers found that teacher sensitivity moderated the association between shyness, peer rejection, and classroom engagement (Buhs et al., 2015). This suggests that teacher sensitivity may function as an important aspect of supportive contexts for shy children. In addition, RimmKaufman et al. (2002) found that sensitive teaching helped to keep children who were 15 months old on task in the classroom. Therefore, close teacher-child relationships may help to aid in the learning process since children with overprotective parents, especially those who are shy, may have a difficult time paying attention and staying on task in the classroom (Coplan, Arbeau, Armer, 2008; Rubin et al., 2009). 
Additionally, researchers have reported that close teacher-child relationships can be beneficial for children who are at risk for poor academic outcomes (Baker, 2006). This is because close relationships with non-familial adults can serve of protective factors for at-risk children (Baker, 2006; Lynch \& Cicchetti, 1991). Empirical evidence of this was found in a study by Peisner-Feinberg and Burchinal (1997) that examined whether child and family characteristics (child's age, child's gender, child's ethnicity, maternal education level, and family income) moderated the relationship between child-care quality and preschool children's cognition and socioemotional development in a diverse sample. The results from this study indicated that there was a positive relationship between teacher-child closeness and children's cognitive and socioemotional outcomes in the classroom (Peisner-Feinberg \& Burchinal, 1997). These positive effects were stronger for children from higher-risk backgrounds (Peisner-Feinberg \& Burchinal, 1997). Thus, it seems reasonable to hypothesize that teacher-child relationships may play a key role in fostering academic self-esteem for children who experience parental overprotection.

\section{Current Study}

Much of the current research on parental overprotection in regards to academic outcomes has focused on adolescents and adult children. However, empirical evidence has shown that overprotective parenting is also associated with negative outcomes in young children as well. These negative outcomes include increased levels of anxiety, depression (Bayer et al., 2006; LeMoyne \& Buchanan, 2011; Schiffrin et al., 2013), and shyness (Rubin et al., 2009; Bayer et al., 2006. Therefore, parental overprotection has significant ramifications on child outcomes in children as young as preschool age (3-5 years). In addition to these known negative outcomes, it is also possible that parental overprotection may be associated with poor academic outcomes as 
well (Cutrona et al., 1994; Padilla-Walker \& Nelson, 2012). For this reason, this study will examine the association between overprotective parenting and academic self-esteem in preschool aged children.

Additionally, previous research has found that close relationships with teachers can help to foster positive academic outcomes in young children (Rudasill \& Rimm-Kaufman, 2009; Buhs et al., 2015). These findings suggest that close relationships with teachers may help to shield young children from the adverse effects of overprotective parenting on children's academic outcomes. For this reason, this study will examine closeness in teacher-child relationships as both an independent variable and as a moderator in relation to the academic self-esteem of preschool aged children.

This study will have three hypotheses. First, parental overprotection is expected to be negatively associated with academic self-esteem in preschool aged children. Teacher closeness is expected to be positively associated with academic self-esteem in preschool aged children. Finally, it is expected that the relationship between parental overprotection and academic selfesteem will be attenuated by teacher closeness. Specifically, it is expected that the strongest negative relation between parental overprotection and academic self-esteem will be for those children whose teachers report low levels of closeness.

\section{Method}

\section{Participants}

A total of 40 mothers completed questionnaires. Demographic data was collected using a demographic questionnaire from mothers who participated in the study. The demographic questionnaire can be found in Appendix A. Although both mother and father demographics were 
collected, only mothers completed questionnaires. Therefore, only maternal characteristics were relevant to the current study. Maternal mean age was $34.41(S D=5.11)$. Most of the mothers identified as white (82.5\%), while there were 5.0\% who identified as Asian, $5.0 \%$ who identified as biracial, and 5.0\% who identified as other. This sample of mothers were highly educated with $27.5 \%$ holding doctoral degrees, $40.0 \%$ holding master's degrees, $15.0 \%$ holding bachelor's degrees, $12.5 \%$ attending some college, and $2.5 \%$ having vocational training. Annual household income levels were also high amongst this sample with $20.0 \%$ being over $\$ 150,000$ per year, $32.5 \%$ being between $\$ 100,000-\$ 150,000$ per year, $15.0 \%$ being between $\$ 75,000-\$ 100,000$ per year, $7.5 \%$ being between $\$ 50,000-\$ 75,000$ per year, $15.0 \%$ being between $\$ 25,000-\$ 50,000$ per year, and $7.5 \%$ being between $\$ 10,000-\$ 25,000$ per year.

As for the children, most were males, $52.5 \%$ of the sample. The mean age of children was $3.72(S D=.68)$ with $37.5 \%$ being 3 years old, $5.0 \%$ being 3.5 years old, $42.5 \%$ being 4 years old, and $12.5 \%$ being 5 years old. As with mothers, most children were White $(82.5 \%)$, while $2.5 \%$ were Asian, $2.5 \%$ were Black, and $10.0 \%$ were biracial. The majority, $92.5 \%$, of children were not Hispanic or Latino.

\section{Measures}

Parenting Practices Questionnaire (Robinson, Mandleco, Olsen, \& Hart, 1995). The 72-item Parenting Practices Questionnaire can be found in Appendix B, and was administered to mothers to assess their global parenting beliefs in relation to authoritative, authoritarian, permissive, and overprotective parenting. Answers to items on this questionnaire were given on a 5-point Likert scale with $1=$ "Never" and 5 = "Always". For the authoritative subscale $(\alpha=.91)$, sample items included "I give praise when my child is good" and "I give comfort and 
understanding when my child is upset." Sample items on the authoritarian subscale $(\alpha=.86)$ included "I punish by taking privileges away from my child with little, if any, explanation" and "I punish by putting my child off somewhere alone with little, if any, explanation." "I spoil my child" and "I allow my child to interrupt others" were items included on the permissive subscale $(\alpha=.75)$. Finally, sample items on the overprotective subscale $(\alpha=.75)$ included "I try to control much of what my child does" and "I tend to be overly involved in my child's activities." Since overprotection was the prime interest of this study, only data collected from the overprotective subscale was analyzed. The Cronbach's alpha for parental overprotection in the current sample was .80.

\section{Student-Teacher Relationship Scale—Short Form (STRS; Pianta \& Steinberg,}

1992). The Student-Teacher Relationship Scale_-Short Form (STRS; Pianta \& Steinberg, 1992) was used to assess teacher-child closeness. This scale can be found in Appendix C and contained 15 items on two subscales, which were the closeness subscale and the conflict subscale. Teachers were asked to rate how applicable each statement was to their current relationship with a particular child on a 5-point Likert scale with $1=$ "definitely does not apply" to $5=$ "definitely applies." The closeness subscale assessed the levels of warmth and open communication in the teacher-child relationship $(\alpha=.90)$. A sample item from this subscale was "I share an affectionate, warm relationship with this child." The conflict subscale assessed conflict in the teacher-child relationship ( $\alpha=.93)$. A sample item was "This child and I always seem to be struggling with each other."

The closeness subscale and the conflict subscale were significantly and negatively correlated with one another $(r=-.67)$. Therefore, a combined closeness aggregate was computed by reverse coding the conflict items and computing the mean for all items (e.g., closeness + 
inverse conflict). The Cronbach's alpha for the closeness aggregate in the current sample was .93.

\section{Behavioral Academic Self-esteem Scale (BASE; Fuchs-Beauchamp, 1996). The} Behavioral Academic Self-esteem Scale (BASE; Fuchs-Beauchamp, 1996) was completed by teachers and used to assess the dependent variable for this study, which was academic selfesteem of preschool aged children. This measure can be found in Appendix D and contained 15 items that examined preschool children's confident approach, adaptability to routines, and ability to deal with failure and frustration $(\alpha=.93)$. Teachers rated how applicable each item was to a specific preschool student on a 5-point Likert scale. Sample items included "Initiates new ideas in classroom" and "Shows self-direction and independence." The Cronbach's alpha for academic self-esteem in the current sample was .93 .

\section{Procedure}

After approval from the Institutional Review Board (IRB) was received, questionnaire packets were prepared by the researcher and delivered to five local preschools that had agreed to participate. Questionnaire packets included an informational flyer that advertised and explained the premise of the study, a consent form, a demographic questionnaire, and the Parenting Practices Questionnaire (Robinson, Mandleco, Olsen, \& Hart, 1995). The consent form expressly asked parents for permission to contact their children's teachers in order for them to complete the corresponding teacher questionnaires. The demographic questionnaire assessed variables, such as annual household income, child race, child ethnicity, maternal race, maternal ethnicity, and maternal education level. Parents who wanted to participate were asked to return their questionnaires to their child's preschool. Each preschool was given an envelope to collect 
returned questionnaires in order to preserve confidentiality. Returned questionnaires were then picked up by the researcher and locked in a drawer for confidentially purposes.

Once researchers received parent questionnaires, corresponding teacher questionnaires were given to the proper preschool for dissemination. Teachers were informed which children to complete questionnaires about in order to make matching parent-teacher pairs. Teacher questionnaires were comprised of the Student-Teacher Relationship Scale-Short Form (STRS; Pianta \& Steinberg, 1992) and the Behavioral Academic Self-Esteem Scale (Fuchs-Beauchamp, 1996). Returned questionnaires were kept in folders until the researcher picked them up and locked them in the file drawer along with the parent questionnaires.

Monetary compensation was provided to both parents and teachers for their participation. Parents received a $\$ 20$ gift card to Target for completing parent questionnaires. Teachers also received a \$20 gift card to Target for completing teacher questionnaires. Since some teachers filled out questionnaires for multiple children, they received a gift card for every teacher questionnaire that they completed.

\section{Results}

During data analysis, descriptive statistics of the independent and dependent variables were generated. The descriptive statistics can be found in Table 1 in Appendix E. For the independent variables, parental overprotection had a mean score of $2.31(S D=.51)$. Since overprotection was reported on a 5-point scale, parental overprotection was moderately low in this sample. The other independent variable, which was the teacher closeness aggregate, had a mean score of $4.40(S D=.67)$. This variable was also reported on a 5-point scale. Thus, in general, teacher closeness was high among this sample. The dependent variable, child academic self-esteem, had a mean score of $3.78(S D=.69)$. Since academic self-esteem was also measured 
on a 5-point scale, the reported mean of academic self-esteem for children in this study was moderate.

Bivariate correlations were conducted among the variables. These correlations can also be found in Table 1. Parental overprotection was found to be significantly negatively correlated with child academic self-esteem $(r=-.38, p<.05)$. It was also found that the teacher closeness aggregate was significantly and positively associated with child academic self-esteem $(r=.70, p$ $<.05)$.

In order to examine potential gender differences, independent samples t-tests were conducted. There was not a significant difference between male children $(M=2.24, S D=.45)$ and female children $(M=2.38, S D=.58)$ in the scores for parental overprotection; $t(36)=-.84, p$ $>$.05. Similarly, there was no significant difference between male children $(M=4.31, S D=79)$ and female children $(M=4.47, S D=.50)$ in the scores for the teacher closeness aggregate $t(28)=$ $-.66, p>.05$. These findings indicate that gender differences were not present in the current sample in relation to parental overprotection and teacher closeness.

One regression analysis was conducted to test the three hypotheses. The predictor variables were entered into the regression as follows: parental overprotection was entered on the first step, the teacher closeness aggregate was entered on the second step, and the interaction between parental overprotection and teacher closeness aggregate was entered on the third step. Child academic self-esteem was the dependent variable. Results of the regression are presented in Table 2 in Appendix E. When overprotection was entered alone, it significantly and negatively predicted child academic self-esteem, $F(1,27)=4.65, p<.05$, adjusted $R^{2}=.12, \beta=-.38$. The teacher closeness aggregate significantly and positively predicted child academic self-esteem, $F(1,26)=13.45, p<.05$, adjusted $R^{2}=.51, \beta=.63$. Finally, the interaction between parental 
overprotection and the teacher closeness aggregate did not predict child academic self-esteem, $F(1,25)=8.67, p>.05$, adjusted $R^{2}=.51$.

\section{Discussion}

The goal of this study was to investigate the individual and combined effects of parental overprotection and teacher closeness on child academic self-esteem. The statistical analysis that was conducted for this study indicated that both parental overprotection and teacher closeness were significant predictors of child academic self-esteem. However, these predictors had opposite outcomes. Specifically, parental overprotection predicted lower child academic selfesteem. Conversely, teacher closeness predicted higher child academic self-esteem. Despite these relationships, the interaction between parental overprotection and teacher closeness was not a predictor of child academic self-esteem.

In regards to parental overprotection, it was hypothesized that overprotective parenting would be negatively associated with academic self-esteem in preschool aged children. The results from this study were consistent with previous studies conducted with older populations of children. Specifically, children in this study whose mothers rated themselves as high in parental overprotection were rated as having lower academic self-esteem by their teachers than their peers whose mothers rated themselves as lower in parental overprotection. These results indicate that parental overprotection is negatively associated with child academic self-esteem. Both PadillaWalker and Nelson (2012) and Cutrona et al. (1994) found similar negative associations between overprotective parenting and academic outcomes in college students. While the results of the current study also indicated that parental overprotection negatively affects child academic outcomes, it expanded the field by examining younger children. 
A relationship between teacher closeness and child academic self-esteem was also found in this study. As expected, children that were rated as having close relationships with their teachers were also rated as having high academic self-esteem. These findings are consistent with those of Rudasill and Rimm-Kaufman (2009) as well as Buhs et al. (2015) that suggest that close, positive teacher-child relationships help to foster positive academic outcomes in young children. Establishing close relationships with teachers in preschool may also foster long-term positive effects. For example, O’Connor and McCartney (2007) found that close teacher-child relationships in preschool promoted academic achievement when children entered the third grade. Thus, early teacher-child relationships, such as those that occur in preschool, may have lasting effects through children's academic careers. For children who are able to establish close teacher-child relationships in preschool, long-term outcomes may include feeling more positively toward school and having higher levels of academic self-esteem than peers who do not establish close relationships with teachers in preschool.

Contrary to expectations, the interaction between parental overprotection and teacher closeness did not predict child academic self-esteem. This result indicates that teacher closeness is not a moderator in the relationship between overprotective parenting and child academic selfesteem. These results can be interpreted to mean that establishing close relationships with teachers does not counterbalance the negative effects of parental overprotection. This is inconsistent with Baker (2006), Lynch and Cicchetti (1991), and Peisner-Feinberg and Burchinal (1997) who found that close relationships with teachers can buffer negative influences on child outcomes. However, the sample in the current study was quite different from samples examined in each of these three previous studies. For example, Baker (2006) examined a large sample of 1,310 children who were diverse in terms of race, ethnicity, and household income. Peisner- 
Feinberg and Burchinal (1997) also obtained a diverse sample in terms of race, ethnicity, and income by targeting four distinct areas within Los Angeles County, California. Finally, Lynch and Cicchetti (1991) examined only children who were maltreated by their parents in their sample. Therefore, the inconsistency of the results of the current study compared to the results of previous studies may be due to vast differences in participant sample.

\section{Limitations}

The small and relatively homogenous sample was a limitation of this study. For example, it is possible that many of the mothers who participated used similar parenting styles because they were all from the same geographic area and were similar in race, ethnicity, age, and income. This would have restricted variance in parental overprotection. Future studies could expand on the current study by examining a more diverse population. Examining parenting practices in a sample of parents who are diverse in terms of race, ethnicity, geographic location, and income would provide better insight to how parenting practices, such as overprotective parenting, affect child academic self-esteem. This is because parents of diverse backgrounds are unlikely to parent in the exact same manner. Similarly, due to the fact that all of the preschools targeted in the current study were located in a moderately affluent suburban area, it is likely that the teachers who participated were warm and sensitive in interactions with children, which would promote close teacher-child relationships (Buhs et al., 2015). This would restrict variance in teacher closeness. As with parents, future studies should target teachers who are diverse in race, children in similar ways and would provide a better insight to how differences in teacher closeness affects child academic self-esteem as well as whether or not teacher closeness moderates the effects of overprotective parenting. 
Another limitation of the current study involved the instrumentations of measurement. Teacher reports were used for both independent and dependent variables. Specifically, teachers completed the Student-Teacher Relationship Scale—-Short Form (STRS; Pianta \& Steinberg, 1992) to assess the independent variable of teacher closeness, and they completed the Behavioral Academic Self-esteem Scale (BASE; Fuchs-Beauchamp, 1996) to assess the dependent variable of child academic self-esteem. This could have resulted in shared method variance. Other studies, such as those conducted with college students, used non-teacher reported measures of academic achievement, such as grade point averages (Cutrona et al., 1994). However, due to the age of the children in this study, measures of academic achievement were not applicable. Since preschool standards examine competencies in areas of language and literacy, math, and science, future researchers could use measures that assess these categories, such as the Peabody Picture Vocabulary Test (Wilson, 1975) or Wechsler Preschool and Primary Scale of Intelligence (Dunn, 1965). These two measures have been used in studies with preschool aged children and were both created to assess cognitive development (Hoffman-Plotkin \& Twentyman, 1984; Wilson 1975; Dunn, 1965). Because cognitive development is, in general, the term that equates to academic achievement in this population, studying this variable may be more similar to studying academic achievement in populations of older children. It is possible that utilizing measures of cognitive development rather than academic self-esteem would have produced different results. This is due to the fact they are two distinctive constructs (Marsh \& O'Mara, 2008). Some children may have been rated as having high academic self-esteem by teachers even though they are not high in cognitive development or vice versa. 


\section{Contributions}

Despite its limitations, this study contributed to the field by examining multiple influences on preschool aged children's academic self-esteem. As is evident from the results of the current study, both parents and teachers are responsible for shaping the academic self-esteem of preschool aged children. With the current trend toward implementing academically rigorous curriculums and learning activities in preschools (Warash et al., 2016), it would be beneficial for communication between parents and teachers to be more open. Having open and positive discussions with children's teachers may help parents to better understand how to best prepare their children for learning (Bundy, 1991). Open communication between parents and teachers may also assist teachers in identifying which children are at-risk for adverse academic outcomes so that additional assistance can be provided to them (Bundy, 1991).

In order to promote parent-teacher relationships, changes in curriculum may be necessary. A reversion to play opportunities rather than structured learning may be a viable option. Engaging in pretend play has been shown to be beneficial for the development and attainment of skills that are necessary for later academic success, such as problem-solving and executive functioning (Bredekamp, 2004). If less importance was placed on academic rigor in preschools, parents may feel less pressure to mold their children to uphold high academic standards at such a young age. In turn, this would perhaps ultimately decrease parental engagement in overprotective behaviors in relation to academics. However, as noted by Warash et al. (2016), many parents currently have adopted the view that academic success is more important than engaging in play. Preschool curriculums could address this issue by creating more take-home activities that would promote pretend play between children and parents. Preschool administrators could also provide more opportunities for parents to engage in play with their 
children while at school through parent volunteer activities, such as story time. Not only would these types of activities promote parental engagement in play, but would also open avenues for teacher-parent communication. Alternatively, highly educated parents, such as the mothers in the current study, could be given literature regarding the importance of play or form community focus groups in which they can discuss this issue. These alternatives may be intellectually stimulating ways in which teachers can stress the cognitive benefits associated with play in preschool aged children to parents.

The results from this study revealed that both parents and teachers play significant roles in shaping children's academic self-esteem at young ages. Specifically, the results revealed that parental overprotection was significantly and negatively associated with children's academic self-esteem. The inverse was found to be true for teacher closeness. In fact, teacher closeness was significantly and positively associated with children's academic self-esteem. Despite these individual associations, there was no significant association between the combined effects of parental overprotection and teacher closeness. This study advanced the field in several ways. In most previous studies related to overprotective parenting and academic outcomes, researchers examined measures of academic achievement, such as grade point averages and standardized tests, in populations of older children (Cutrona et al., 1994; Padilla-Walker \& Nelson, 2012). Therefore, this study advanced the field by specifically investigating academic self-esteem rather than academic achievement and by examining these associations in younger populations of children. Additionally, this study contributed insight regarding the multiple influences on academic self-esteem in young children since both parent and teacher factors were examined. 


\section{References}

Ainsworth, M.D., \& Bell, S.M. (1970). Attachment, exploration, and separation: Illustrated by the behavior of one-year-olds in a strange situation. Child Development, 41(1), 49-76.

Baker, J. A. (2006). Contributions of teacher-child relationships to positive school adjustment during elementary school. Journal of School Psychology, 44(3), 211-229. doi: 10.1016/j.jsp.2006.02.002

Barber, B. K. (1996). Parental psychological control: Revisiting a neglected construct. Child Development, 67, 3296-3319.

Barber, B. K., Olsen, J. E., \& Shagle, S. C. (1994). Associations between parental psychological and behavioral control and youth internalized and externalized behaviors. Child Development, 65, 1120-1136.

Barnett, D., Kidwell. S. L., \& Leung, K. H. (1998). Parenting and preschooler attachment among low-income urban african american families. Child Development, 69(6), 1657-1671. doi: 10.1111/j.1467-8624.1998.tb06183.x

Baumrind, D. (1966). Effects of authoritative parental control on child behavior. Child Development, 37(4), 887-907. doi: 10.2307/1126611

Bayer, J. K., Sanson, A. V., \& Hemphill, S. A. (2006). Parent influences on early childhood internalizing difficulties. Journal of Applied Developmental Psychology, 27(6), 542-559. doi: 10.1016/j.appdev.2006.08.002

Belfield, C., \& Garcia, E. (2014). Parental notions of school readiness: How have they changed and has preschool made a difference?. Journal of Educational Research, 107, 138-151.

Bernstein, G., \& Triger, Z. (2010). Over-parenting. UC Davis Law Review, 44, 1221- 1279. 
Bethke, J. A. (2011). Highly involved parents of college students: A literature review (Master's thesis). Retrieved from http://citeseerx.ist.psu.edu/viewdoc/download?doi=10.1.1.389.8389 $\&$ rep=rep $1 \&$ type $=$ pdf

Birch, S. H., \& Ladd, G. W. (1997). The teacher-child relationship and children's early school adjustment. Journal of School Psychology, 35(1), 61-79. doi: 10.1016/S00224405(96)00029-5

Bowlby, J. (1977). The making and breaking of affectional bonds. I. Aetiology and psychopathology in the light of attachment theory. The British Journal Of Psychiatry, 130201-210. doi:10.1192/bjp.130.3.201

Brantlinger, E. A. (2003). Dividing classes: How the middle class negotiates and rationalizes school advantage. New York: RoutledgeFalmer.

Bredekamp, S. (2004). Play and school readiness. In E. F. Zigler, D. G. Singer, \& S. J. BishopJosef (Eds.), Children's play: The roots of reading (pp. 159-174). Washington, DC: Zero to Three.

Buhs, E. S., Rudasill, K. M., Kalutskaya, I. N., Griese, E. R. (2015). Shyness and engagement: Contributions of peer rejection and teacher sensitivity. Early Childhood Research Quarterly, 30(1), 12-19. doi: 10.1016/j.ecresq.2014.07.010

Bundy, B. F. (1991). Fostering communication between parents and preschools. Young Children, $46(2), 12-17$. 
Buyse, E., Verschueren, K., \& Doumen, S. (2011). Preschoolers' attachment to mother and risk for adjustment problems in kindergarten: Can teachers make a difference?. Social Development, 20(1), 33-50. doi:10.1111/j.1467-9507.2009.00555.x

Chickering, A. W. (1969). Education and identity. San Francisco: Jossey-Bass.

Cohen, J. (1992). A power primer. Psychological Bulletin, 112(1), 155-159.

Coplan, R. J., Arbeau, K. A., \& Armer, M. (2008). Don't fret, be supportive! Maternal characteristics linking child shyness to psychosocial and school adjustment in kindergarten. Journal of Abnormal Child Psychology, 36(3), 359-371.

Coplan, R. J., Gavinski-Molina, M. H., Lagace-Seguin, D., \& Wichmann, C. (2001). When girls versus boys play alone: Gender differences in the associates of nonsocial play in kindergarten. Developmental Psychology, 37, 464-474.

Cutrona, C. E., Cole, V., Colangelo, N., Assouline, S. G., \& Russell, D. W. (1994). Perceived parental social support and academic achievement: An attachment theory perspective. Journal of Personality and Social Psychology, 66(2), 369-378. doi: 10.1037/0022-3514.66.2.369

Dunn, L. (1965). Peabody Picture Vocabulary Test. Circle Pines, MN: American Guidance Service.

Egger, H. L., Erkanli, A., Keeler, G., Potts, E., Walter, B. K., \& Angold, A. (2006). Test-retest reliability of the preschool age psychiatric assessment (papa). Journal of the American Academy of Child and Adolescent Psychiatry, 45(5), 538-549. doi:

10.1097/01.chi.0000205705.71194.b8 
Fuchs-Beauchamp, K. D. (1996). Preschoolers' inferred self-esteem: The behavioral rating scale of presented self-esteem in young children. The Journal of Genetic Psychology, 157(2), 204-210.

Hastings, P. D., Nuselovici, J. N., Rubin, K. H., \& Cheah, C. S. L. (2010). Shyness, parenting and parent-child relationships. In K. H. Rubin \& R. J. Coplan (Eds.), The development of shyness and social withdraw (pp. 107-141). New York, NY: The Guilford Press.

Hoffman-Plotkin, D., \& Twentyman, C. T. (1984). A multimodal assessment of behavioral and cognitive deficits in abused and neglected preschoolers. Child Development, 55(3), 794.802.

Jackson, J.F. (1993). Human Behavioral Genetics Scarr's Theor, and her Views on Interventions: A critical review and commentary on their implications for African American Children. Child Development, 64, 1318-1332.

Jeynes, W. H. (2003). A meta-analysis: The effects of parental involvement on minority children's academic achievement. Education and Urban Society, 35(2), 202-218. doi: 10.117710013124502239392

Karavasilis, L., Doyle, A. B. \& Markiewicz, D. (2003). Associations between parenting style and attachment to mother in middle childhood adolescence. International Journal of Behavioral Development, 27(2), 153-164.ISSN: 0165-0254. doi: $10.1080 / 0165025024400015$

Lareau, A. (2011). Unequal Childhoods. Oakland, CA: University of California Press. 
LeMoyne, T., \& Buchanan, T. (2011). Does "hovering" matter? Helicopter parenting and its effect on well-being. Social Spectrum: Mid-South Sociological Association, 31(4), 399418. doi: $10.1080 / 02732173.2001 .574038$

Lloyd, B., \& Howe, N. (2003). Solitary play and convergent and divergent thinking skills in preschool children. Early Childhood Research Quarterly, 18(1), 22-41. doi: $10.1016 / \mathrm{S} 0885-2006(03) 00004-8$

Lynch, M., \& Cicchetti, D. (1991). Patterns of relatedness in maltreated and nonmaltreated children: Connections among multiple representational models. Development and Psychopathology, 3(2), 207-226.

Marsh, H. W., \& O'Mara, A. (2008). Reciprocal effects between academic self-concept, selfesteem, achievement, and attainment over seven adolescent years: Unidimensional and multidimensional perspectives of self-concept. Personality and Social Psychology Bulletin, 34(4), 542-552. doi: 10.1177/0146167207312313

Milkie, M. A., Mattingly, M. J., Nomaguchi, K. M., Bianchi, S. M., \& Robinson, J. P. (2004). The time squeeze: Parental statuses and feelings about time with children. Journal of Marriage and Family, 66(3), 739-761.

Mills, R. S., \& Rubin, K. H. (1998). Are behavioural and psychological control both differentially associated with childhood aggression and social withdrawal?. Canadian Journal of Behavioural Science, 30(2), 132-136. 
O’Connor, E., \& McCartney, K. (2007). Examining teacher-child relationships and achievement as part of an ecological model of development. American Educational Research Journal, 44(2), 340-369. doi: 10.3102/0002831207302172

Padilla-Walker, L., \& Nelson, L.J. (2012). Black hawk down?: Establishing helicopter parenting as a distinct construct from other forms of parental control during emergency adulthood. Journal of Adolescence, 3, 1177-1190. doi: 10.1016/j.adolescence.2012.03.007

Pallas, A. M., Entwisle, D. R., Alexander, K. L., \& Cadigan, D. (1987). Children who do exceptionally well in first grade. Sociology of Education, 60, 251-271.

Peisner, E. S., \& Burchinal, M. R. (1997). Relations between preschool children's child-care experiences and concurrent development: The cost, quality, and outcomes study. MerrillPalmer Quarterly, 43(3), 451-477.

Pianta, R. C., \& Steinberg, M. (1992). Teacher-child relationships and the process of adjusting to school. New Directions for Child and Adolescent Development, 1992(57), 61-80. doi: $10.1002 / \mathrm{cd} .23219925706$

Rimm-Kaufman, S. E., Early, D. M., Cox, M. J., Saluja, G., Pianta, R. C., Bradley, R. H., \& Payne, C. (2002). Early behavioral attributes and teachers' sensitivity as predictors of competent behavior in the kindergarten classroom. Journal of Applied Developmental Psychology, 23(4), 451-470. doi: 10.1016/S0193-3973(02)00128-4

Robinson, C. C., Mandleco, B., Olsen, S. F., \& Hart, C. H. (1995). Authoritative, authoritarian, and permissive parenting practices: Development of a new measure. Psychological Reports, 77, 819-830. 
Rubin, K. H., Burgess, K., B., \& Hastings, P. D. (2002). Stability and social-behavioral consequences of toddlers' inhibited temperament and parenting behaviors. Child Development, 73(2), 483-495.

Rubin, K. H., Coplan, R. J., \& Bowker, J. C. (2009). Social withdrawal in childhood. Annual Review of Psychology, 60, 141-171. doi: 10.1146/annurev.osych.60.11070.163642

Rubin, K. H., Hastings, P. D., Stewart, S. L., Henderson, H. A., \& Chen, W. (1997). The consistency and concomitants of inhibition: Some of the children, all of the time. Child Development, 68(3), 467-483. doi: 10.1111/j.1467-8624.1997.tb01952.x

Rudasill, K. M., \& Rimm-Kaufman, S. E. (2009). Teacher-child relationship quality: The roles of child temperament and teacher-child interactions. Early Childhood Research Quarterly, 24(2), 107-120. doi: 10.1016/j.ecresq.2008.12.03

Schiffrin, H. H., Liss, M., Miles-McLean, H., Geary, K. A., Erchull, M. J., \& Tashner, T. (2013). Helping or hovering? The effects of helicopter parenting on college students' well-being. Journal of Child and Family Studies, 23, 548-557. doi: 10.1007/s10826-013-9716-3

Schweinhart, L. J., \& Weikart, D. P. (1997). The high/scope preschool curriculum comparison study through age 23. Early Childhood Research Quarterly, 12(2), 117-143. doi: 10.1016/S0885-2006(97)90009-0

Senior, J. (2014). All Joy and No Fun. New York: Harper Collins.

Shine, S., \& Acosta, T. Y. (2000). Parent-child social play in a children's museum. Family Relations, 49(1), 45-52. 
Simpson, J. A. (1990). Influence of attachment styles on romantic relationships. Journal of Personality and Social Psychology, 59(5), 971-980. doi: 10.1037/0022-3514.59.5.971

Warash, B. G., Root, A. E., \& Doris, M. D. (2016). Parents' perceptions of play: A comparative study of spousal perspectives. Early Child Development and Care, 1-9.

West Virginia Department of Education. (2013). Early Learning Standards Framework for West Virginia Pre-K [Brochure]. Charleston, WV.

Williams, L. R., Degnan, K. A., Perez-Edgar, K., Henderson, H. A., Rubin, K. H., Pine, D. S., Steinberg, L., \& Fox, N. A. (2009). Impact of behavioral inhibition and parenting style on internalizing and externalizing problems from early childhood through adolescence. Journal of Abnormal Child Psychology, 37(8), 1063-1075. doi: 10.1007/s10802-0099331-3

Wilson, R. S. (1975). Twins: Patterns of cognitive development as measured on the Wechsler preschool and primary scale of intelligence. Developmental Psychology, 11(2), 126-134.

Wood, J. J., McLeod, B, D., Sigman, M., Hwang, W., \& Chu, B. C. (2003). Parenting and childhood anxiety: theory, empirical findings, and future directions. Journal of Child Psychology and Psychiatry, 44(1), 134-151. 


\section{Appendix A}

\section{Demographic Information}

1. Child's First Name:

2. Name of child's school:

3. Name of child's teacher:

4. Your Name:

5. Are you the child's:

$\square$ Mother

$\square$ Father

$\square$ Other (please specify)

5. Date:

6. Child's Birthdate: (Month/Date/Year):

7. Child's Age:

8. Child's Sex (circle one): MALE FEMALE

9. Child's Country of Birth:

10. Is your child biological? Adopted? Foster child?

11. Child's Ethnicity (circle one):

$\square$ Hispanic or Latino

Not Hispanic or Latino

12. Child's Race (circle one):

American Indian/Alaska Native

Asian

Black or African American 


\section{Appendix A}

$\square$ Native Hawaiian or Other Pacific Islander

$\square$ White or Caucasian

Bi- or Multi-racial (please specify):

$\square$ Other (please specify):

13. Mother's Birthdate (Month/Date/Year):

14. Mother's Age:

15. Mother's Occupation:

16. What the mother's employment status (check one):

$\square$ Employed full-time

$\square$ Employed part-time

$\square$ Not employed outside of home

$\square$ Retired

$\square$ Unemployed

$\square$ Other (specify):

17. Mother's education level (check one):

$\square$ Elementary School

$\square$ High School

$\square$ Vocational School

$\square$ Some College

$\square$ University Degree

$\square$ Some Graduate School

$\square$ Master's Degree

$\square$ Doctoral Degree 


\section{Appendix A}

$\square$ Other (specify):

18. Mother's country of birth:

19. If mother was not born in the U.S., how long has she been residing in the U.S. (check one)?

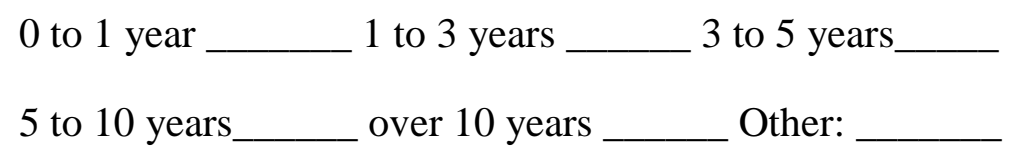

20. Mother's Ethnicity (circle one):

Hispanic or Latino

Not Hispanic or Latino

21. Mother's Race (circle one):

American Indian/Alaska Native

Asian

Black or African American

Native Hawaiian or Other Pacific Islander

White or Caucasian

Bi- or Multi-racial (please specify):

Other (please specify):

22. What language is spoken most often in your home (check one)?

English __ Chinese __ $\_$Spanish $\_$
Filipino __ Japanese ___ Korean $\_$

Malaysian ___ Other (specify)

23. Mother's Marital Status with child's father (check one):

Married How long? 


\section{Appendix A}

Separated How long?

Divorced How long?

Common law

Other (specify)

24. Mother's current relationship status (check one):

$\square$ Married

$\square$ Separated

$\square$ Divorced

$\square$ Common law

$\square$ Single

$\square$ Living with partner

$\square$ Other (specify):

25. Child's Father's Birthdate (Month/Date/Year):

26. Father's Age:

27. Father's Occupation:

28. What is the father's employment status (check one):

$\square$ Employed full-time

$\square$ Employed part-time

$\square$ Not employed outside of home

$\square$ Retired

$\square$ Unemployed

$\square$ Other (specify): 


\section{Appendix A}

29. Father's education level (check one):

$$
\begin{aligned}
& \square \text { Elementary School } \\
& \square \text { High School } \\
& \square \text { Vocational School } \\
& \square \text { Some College } \\
& \square \text { University Degree } \\
& \square \text { Some Graduate School } \\
& \square \text { Master's Degree } \\
& \square \text { Doctoral Degree } \\
& \square \text { Other (specify): }
\end{aligned}
$$

30. Father's country of birth:

31. If father was not born in the U.S., how long has he been residing in the U.S. (check one)?

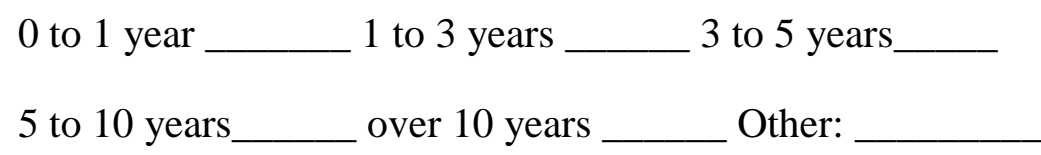

32. Father's Ethnicity (circle one):

Hispanic or Latino

Not Hispanic or Latino

33. Father's Race (circle one):
American Indian/Alaska Native
Asian
Black or African American
Native Hawaiian or Other Pacific Islander
White or Caucasian 


\section{Appendix A}

Bi- or Multi-racial (please specify):

Other (please specify):

34. Father's Marital Status with child's mother (check one):

Married How long?

Separated How long?

Divorced How long?

Common law

Other (specify)

35. Father's current relationship status (check one):

$\square$ Married

$\square$ Separated

$\square$ Divorced

$\square$ Common law

$\square$ Single

$\square$ Living with partner

$\square$ Other (specify):

36. Household Income (circle one): Less than $\$ 10,000$

$$
\begin{aligned}
& \$ 10,000-\$ 25,000 \\
& \$ 25,000-\$ 50,000 \\
& \$ 50,000-\$ 75,000 \\
& \$ 75,000-\$ 100,000 \\
& \$ 100,000-\$ 150,000
\end{aligned}
$$

Greater than $\$ 150,000$ 
Appendix B

\title{
PARENTING PRACTICES QUESTIONNAIRE
}

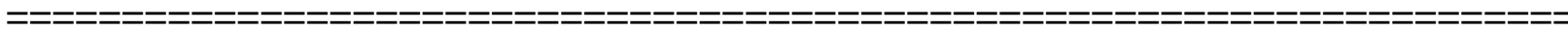

Make one rating for each item; rate how often you exhibit this behavior with your child

I Exhibit This Behavior:

$$
\begin{aligned}
& 1=\text { Never } \\
& 2=\text { Once in Awhile } \\
& 3=\text { About Half of the Time } \\
& 4=\text { Very Often } \\
& 5=\text { Always }
\end{aligned}
$$

1. I encourage my child to talk about the child's troubles.

2. I guide my child by punishment more than by reason.

3. I know the names of my child's friends.

4. I find it difficult to discipline my child.

5. I give praise when my child is good.

6. I spank when my child is disobedient.

7. I joke and play with my child.

8. I withhold scolding and / or criticism even when my child acts contrary to my wishes.

9. I show sympathy when my child is hurt or frustrated.

10. I punish by taking privileges away from my child with little if any explanation.

11. I spoil my child.

12. I give comfort and understanding when my child is upset.

13. I yell or shout when my child misbehaves.

14. I am easy going and relaxed with my child. 
Appendix B

\title{
PARENTING PRACTICES QUESTIONNAIRE
}

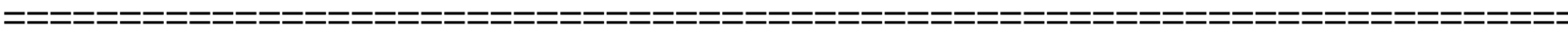

Make one rating for each item; rate how often you exhibit this behavior with your child

I Exhibit This Behavior:

$$
\begin{aligned}
& 1=\text { Never } \\
& 2=\text { Once in Awhile } \\
& 3=\text { About Half of the Time } \\
& 4=\text { Very Often } \\
& 5=\text { Always }
\end{aligned}
$$

15. I allow my child to annoy someone else.

16. I tell my child my expectations regarding behavior before the child engages in an activity.

17. I scold and criticize to make my child improve.

18. I show patience with my child.

19. I grab my child when being disobedient.

20. I state punishments to my child and do not actually do them.

21. I am responsive to my child's feelings or needs.

22. I allow my child to give input into family rules.

23. I argue with my child.

24. I appear confident about parenting abilities.

25 . I give my child reasons why rules should be obeyed.

26. I appear to be more concerned with my own feelings than with my child's feelings.

27. I tell my child that we appreciate what the child tries or accomplishes. 
Appendix B

\title{
PARENTING PRACTICES QUESTIONNAIRE
}

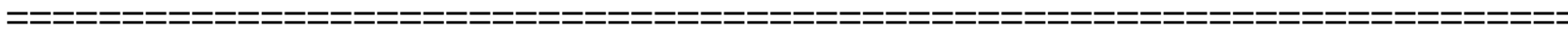

Make one rating for each item; rate how often you exhibit this behavior with your child

I Exhibit This Behavior:

$$
\begin{aligned}
& 1=\text { Never } \\
& 2=\text { Once in Awhile } \\
& 3=\text { About Half of the Time } \\
& 4=\text { Very Often } \\
& 5=\text { Always }
\end{aligned}
$$

28. I punish by putting my child off somewhere alone with little, if any, explanation.

29. I help my child to understand the impact of behavior by encouraging my child to talk about the consequences of own actions.

30. I am afraid that disciplining my child for misbehavior will cause the child not to like her/ his parents.

31. I take my child's desires into account before asking the child to do something.

32. I explode in anger towards my child.

33. I am aware of problems or concerns about my child in school.

34. I threaten my child with punishment more often than actually giving it.

35. I express affection by hugging, kissing, and holding my child.

36. I ignore my child's misbehavior.

37. I use physical punishment as a way of disciplining my child.

38. I carry out discipline after my child misbehaves.

39. I apologize to my child when making a mistake in parenting.

40. I tell my child what to do. 
Appendix B

\title{
PARENTING PRACTICES QUESTIONNAIRE
}

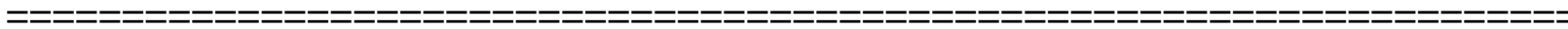

Make one rating for each item; rate how often you exhibit this behavior with your child

I Exhibit This Behavior:

$$
\begin{aligned}
& 1=\text { Never } \\
& 2=\text { Once in Awhile } \\
& 3=\text { About Half of the Time } \\
& 4=\text { Very Often } \\
& 5=\text { Always }
\end{aligned}
$$

41. I give in to my child when the child causes a commotion about something.

42. I talk it over and reason with my child when the child misbehaves.

43. I slap my child when the child misbehaves.

44. I disagree with my child.

45. I allow my child to interrupt others.

46. I have warm and intimate times together with my child.

47. When two children are fighting, I discipline the children first and ask questions later.

48. I encourage my child to freely express herself/himself even when disagreeing with parents.

49. I bribe my child with rewards to bring about compliance.

50. I scold or criticize when my child's behavior doesn't meet my expectation.

51. I show respect for my child's opinions by encouraging my child to express them.

52. I set strict well-established rules for my child.

53. I explain to my child how I feel about my child's good and bad behavior. 
Appendix B

\title{
PARENTING PRACTICES QUESTIONNAIRE
}

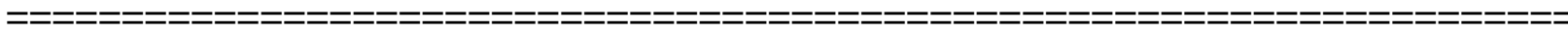

Make one rating for each item; rate how often you exhibit this behavior with your child

I Exhibit This Behavior:

$$
\begin{aligned}
& 1=\text { Never } \\
& 2=\text { Once in Awhile } \\
& 3=\text { About Half of the Time } \\
& 4=\text { Very Often } \\
& 5=\text { Always }
\end{aligned}
$$

54. I use threats as punishment with little or no justification.

55. I take into account my child's preferences in making plans for the family.

56. When my child asks why s/he has to conform, I state: "because I said so", or "I am your parent and I want you to."

57. I appear unsure on how to solve my child's misbehavior.

58. I explain the consequences of the child's behavior.

59. I demand that my child does things.

60. I channel my child's misbehavior into a more acceptable activity.

61. I shove my child when the child is disobedient.

62. I emphasize the reasons for rules.

63. I intervene if there is a chance that my child will fail at something.

64. I get anxious when my child tries to do something new or difficult for him/her.

65. I feel guilty when my child does not measure up to his/her potential.

66. I am fearful that others will not think well of my child. 
Appendix B

\section{PARENTING PRACTICES QUESTIONNAIRE}

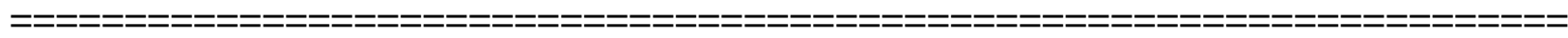

Make one rating for each item; rate how often you exhibit this behavior with your child

\section{Exhibit This Behavior:}

$$
\begin{aligned}
& 1=\text { Never } \\
& 2=\text { Once in Awhile } \\
& 3=\text { About Half of the Time } \\
& 4=\text { Very Often } \\
& 5=\text { Always }
\end{aligned}
$$

67. I try to control much of what my child does.

68. I think it is important to supervise all of my child's activities.

69. I discourage my child from trying new things if there is a chance my child will fail.

70. I expect my child to be close by when playing.

71. I tend to be overly involved in my child's activities.

72. I tend to be overly protective with my child. 


\section{Appendix C}

\section{Student-Teacher Relationship Scale - Short Form}

Child:

Teacher:

Grade:

Please reflect on the degree to which each of the following statements currently applies to your relationship with this child. Using the scale below, circle the appropriate number for each item.

$\begin{array}{ccccc}\text { Definitely } & \text { Not } & \text { Neutral, } & \text { Applies } & \text { Definitely } \\ \text { does not } & \text { really } \\ \text { apply } & & \text { not sure } & \begin{array}{c}\text { some- } \\ \text { what }\end{array} & \begin{array}{c}\text { applies } \\ \end{array}\end{array}$

1. I share an affectionate, warm relationship with this child.

2. This child and I always seem to be struggling with each other.

2

3

4

5

3. If upset, this child will seek comfort from me.

4. This child is uncomfortable with physical affection or touch from me.

5. This child values his/her relationship with me.

6. When I praise this child, he/she beams with pride.

7. This child spontaneously shares information about himself/herself.

8. This child easily becomes angry with me.

9. It is easy to be in tune with what this child is feeling.

10. This child remains angry or is resistant after being disciplined.

11. Dealing with this child drains my energy.

12. When this child is in a bad mood, I know we're in for a long and difficult day.

13. This child's feelings toward me can be unpredictable or can change suddenly.

14. This child is sneaky or manipulative with me.

15. This child openly shares his/her feelings and experiences with me.
1

1

1

1

1

1

1

1

1

1

1

1

1

(

2

\section{3}

3

4

5

\section{2}

4

5

T

\section{2}

3

4

4

4

5




\section{Appendix D}

\section{Behavioral Academic Self-esteem: A Rating Scale}

DIRECTIONS: This scale is designed to provide an estimate of the academic selfesteem of your student. Your judgments of the frequencies of several important behaviors will form the basis of the student's score. Please base these judgments on the specific behaviors you have observed in your classroom.

Each item deals with a separate behavior. Items may appear similar, but each represents a different behavior and should be rated without regard or reference to other items

Please circle the rating number (i.e., 1 through 5) that you believe is the best estimate of that behavior frequency noted in your classroom. It is best not to debate or linger over an item. Most ratings can be completed in less than four minutes.

Student Name:

Age: Sex:

Grade:

School:

Rater Name: Date:

Never Seldom Sometimes Usually Always

1. This child is willing to undertake new tasks.

2. This child is able to make decisions regarding things that affect him or her, e.g., establishing goals, making choices, regarding "likes" and "dislikes" or academic interests.

3. This child shows self-direction and independence in activities.

4. This child initiates new ideals relative to classroom activities and projects.

5. This child asks questions when she or he does not understand.

6. This child adapts easily to changes in procedures.

7. This child is quiet in class, speaks in turn, and talks appropriately.

8. This child talks appropriately about his or her school accomplishments.

9. This child cooperates with other children.

1

1

1

2

3

4

5 ,

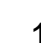

1

1

1

1

1

1

1
1

1

1

\begin{tabular}{|c|c|c|c|}
\hline \multicolumn{4}{|c|}{$\begin{array}{l}\text { Rating Scale } \\
\text { e academic self- } \\
\text { veral important } \\
\text { these judgments on } \\
\text { ear similar, but each } \\
\text { or reference to } \\
\text { believe is the best } \\
\text { best not to debate or } \\
\text { ur minutes. }\end{array}$} \\
\hline \multicolumn{4}{|c|}{ Date: } \\
\hline Seldom & Sometimes & Usually & Alwa) \\
\hline 2 & 3 & 4 & 5 \\
\hline 2 & 3 & 4 & 5 \\
\hline 2 & 3 & 4 & 5 \\
\hline 2 & 3 & 4 & 5 \\
\hline 2 & 3 & 4 & 5 \\
\hline 2 & 3 & 4 & 5 \\
\hline 2 & 3 & 4 & 5 \\
\hline
\end{tabular}

\begin{tabular}{|c|c|c|c|}
\hline \multicolumn{4}{|c|}{$\begin{array}{l}\text { Rating Scale } \\
\text { e academic self- } \\
\text { veral important } \\
\text { these judgments on } \\
\text { ear similar, but each } \\
\text { or reference to } \\
\text { believe is the best } \\
\text { best not to debate or } \\
\text { ur minutes. }\end{array}$} \\
\hline \multicolumn{4}{|c|}{ Date: } \\
\hline Seldom & Sometimes & Usually & Alwa) \\
\hline 2 & 3 & 4 & 5 \\
\hline 2 & 3 & 4 & 5 \\
\hline 2 & 3 & 4 & 5 \\
\hline 2 & 3 & 4 & 5 \\
\hline 2 & 3 & 4 & 5 \\
\hline 2 & 3 & 4 & 5 \\
\hline 2 & 3 & 4 & 5 \\
\hline
\end{tabular}

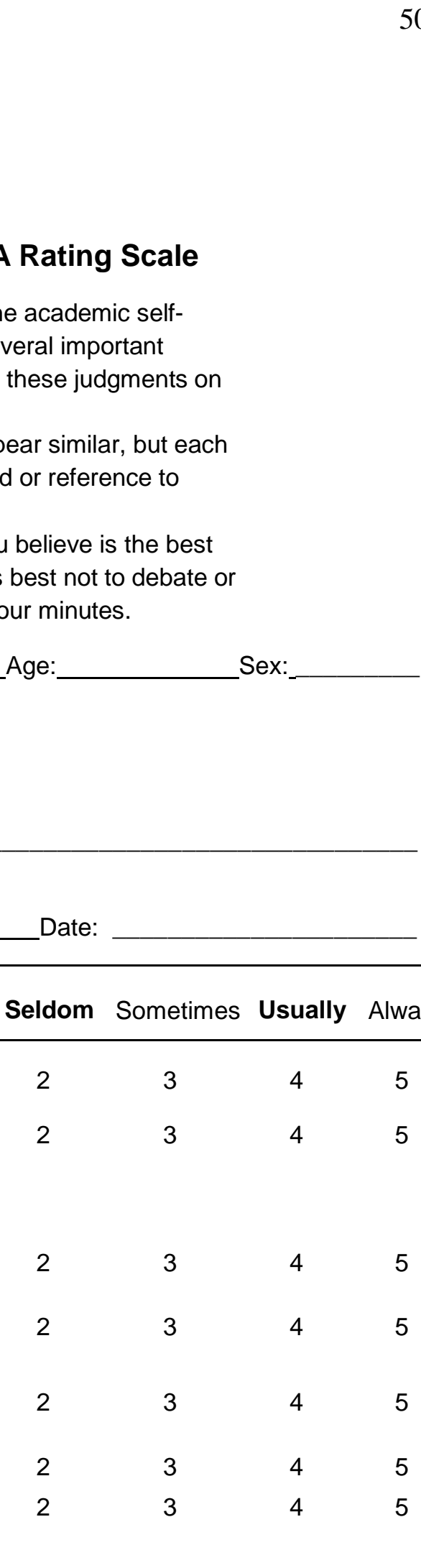

\begin{tabular}{|c|c|c|c|}
\hline \multicolumn{4}{|c|}{$\begin{array}{l}\text { Rating Scale } \\
\text { e academic self- } \\
\text { veral important } \\
\text { these judgments on } \\
\text { ear similar, but each } \\
\text { or reference to } \\
\text { believe is the best } \\
\text { best not to debate or } \\
\text { ur minutes. }\end{array}$} \\
\hline \multicolumn{4}{|c|}{ Date: } \\
\hline Seldom & Sometimes & Usually & Alwa) \\
\hline 2 & 3 & 4 & 5 \\
\hline 2 & 3 & 4 & 5 \\
\hline 2 & 3 & 4 & 5 \\
\hline 2 & 3 & 4 & 5 \\
\hline 2 & 3 & 4 & 5 \\
\hline 2 & 3 & 4 & 5 \\
\hline 2 & 3 & 4 & 5 \\
\hline
\end{tabular}

\begin{tabular}{|c|c|c|c|}
\hline \multicolumn{4}{|c|}{$\begin{array}{l}\text { Rating Scale } \\
\text { e academic self- } \\
\text { veral important } \\
\text { these judgments on } \\
\text { ear similar, but each } \\
\text { or reference to } \\
\text { believe is the best } \\
\text { best not to debate or } \\
\text { ur minutes. }\end{array}$} \\
\hline \multicolumn{4}{|c|}{ Date: } \\
\hline Seldom & Sometimes & Usually & Alwa) \\
\hline 2 & 3 & 4 & 5 \\
\hline 2 & 3 & 4 & 5 \\
\hline 2 & 3 & 4 & 5 \\
\hline 2 & 3 & 4 & 5 \\
\hline 2 & 3 & 4 & 5 \\
\hline 2 & 3 & 4 & 5 \\
\hline 2 & 3 & 4 & 5 \\
\hline
\end{tabular}

\begin{tabular}{|c|c|c|c|}
\hline \multicolumn{4}{|c|}{$\begin{array}{l}\text { Rating Scale } \\
\text { e academic self- } \\
\text { veral important } \\
\text { these judgments on } \\
\text { ear similar, but each } \\
\text { or reference to } \\
\text { believe is the best } \\
\text { best not to debate or } \\
\text { ur minutes. }\end{array}$} \\
\hline \multicolumn{4}{|c|}{ Date: } \\
\hline Seldom & Sometimes & Usually & Alwa) \\
\hline 2 & 3 & 4 & 5 \\
\hline 2 & 3 & 4 & 5 \\
\hline 2 & 3 & 4 & 5 \\
\hline 2 & 3 & 4 & 5 \\
\hline 2 & 3 & 4 & 5 \\
\hline 2 & 3 & 4 & 5 \\
\hline 2 & 3 & 4 & 5 \\
\hline
\end{tabular}

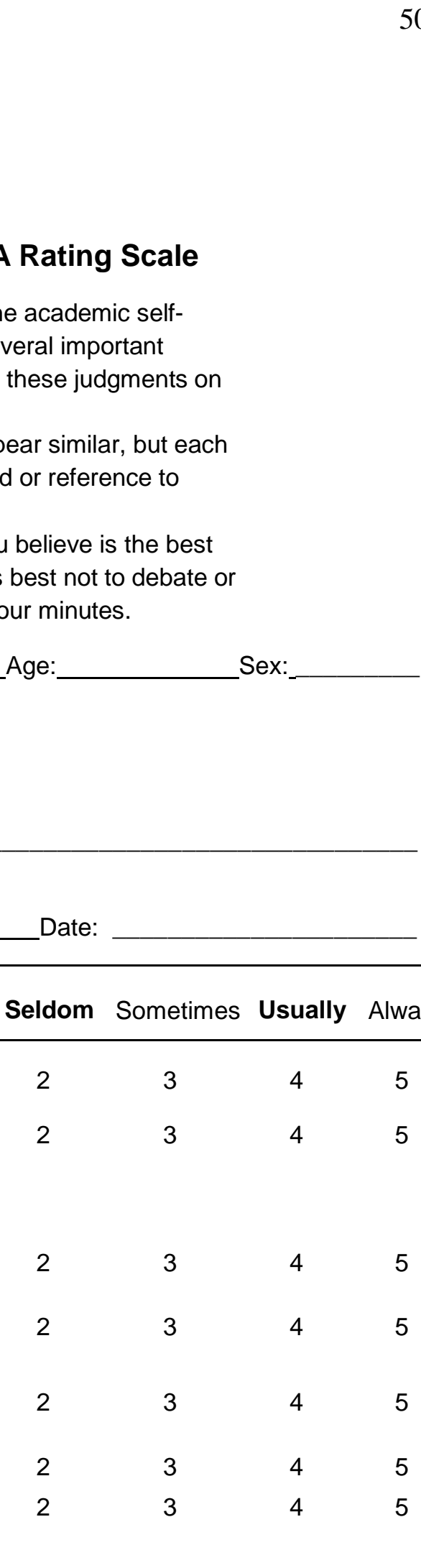

\begin{tabular}{|c|c|c|c|}
\hline \multicolumn{4}{|c|}{$\begin{array}{l}\text { Rating Scale } \\
\text { e academic self- } \\
\text { veral important } \\
\text { these judgments on } \\
\text { ear similar, but each } \\
\text { or reference to } \\
\text { believe is the best } \\
\text { best not to debate or } \\
\text { ur minutes. }\end{array}$} \\
\hline \multicolumn{4}{|c|}{ Date: } \\
\hline Seldom & Sometimes & Usually & Alwa) \\
\hline 2 & 3 & 4 & 5 \\
\hline 2 & 3 & 4 & 5 \\
\hline 2 & 3 & 4 & 5 \\
\hline 2 & 3 & 4 & 5 \\
\hline 2 & 3 & 4 & 5 \\
\hline 2 & 3 & 4 & 5 \\
\hline 2 & 3 & 4 & 5 \\
\hline
\end{tabular}

\begin{tabular}{|c|c|c|c|}
\hline \multicolumn{4}{|c|}{$\begin{array}{l}\text { Rating Scale } \\
\text { e academic self- } \\
\text { veral important } \\
\text { these judgments on } \\
\text { ear similar, but each } \\
\text { or reference to } \\
\text { believe is the best } \\
\text { best not to debate or } \\
\text { ur minutes. }\end{array}$} \\
\hline \multicolumn{4}{|c|}{ Date: } \\
\hline Seldom & Sometimes & Usually & Alwa) \\
\hline 2 & 3 & 4 & 5 \\
\hline 2 & 3 & 4 & 5 \\
\hline 2 & 3 & 4 & 5 \\
\hline 2 & 3 & 4 & 5 \\
\hline 2 & 3 & 4 & 5 \\
\hline 2 & 3 & 4 & 5 \\
\hline 2 & 3 & 4 & 5 \\
\hline
\end{tabular}

\begin{tabular}{|c|c|c|c|}
\hline \multicolumn{4}{|c|}{$\begin{array}{l}\text { Rating Scale } \\
\text { e academic self- } \\
\text { veral important } \\
\text { these judgments on } \\
\text { ear similar, but each } \\
\text { or reference to } \\
\text { believe is the best } \\
\text { best not to debate or } \\
\text { ur minutes. }\end{array}$} \\
\hline \multicolumn{4}{|c|}{ Date: } \\
\hline Seldom & Sometimes & Usually & Alwa) \\
\hline 2 & 3 & 4 & 5 \\
\hline 2 & 3 & 4 & 5 \\
\hline 2 & 3 & 4 & 5 \\
\hline 2 & 3 & 4 & 5 \\
\hline 2 & 3 & 4 & 5 \\
\hline 2 & 3 & 4 & 5 \\
\hline 2 & 3 & 4 & 5 \\
\hline
\end{tabular}

\begin{tabular}{|c|c|c|c|}
\hline \multicolumn{4}{|c|}{$\begin{array}{l}\text { Rating Scale } \\
\text { e academic self- } \\
\text { veral important } \\
\text { these judgments on } \\
\text { ear similar, but each } \\
\text { or reference to } \\
\text { believe is the best } \\
\text { best not to debate or } \\
\text { ur minutes. }\end{array}$} \\
\hline \multicolumn{4}{|c|}{ Date: } \\
\hline Seldom & Sometimes & Usually & Alwa) \\
\hline 2 & 3 & 4 & 5 \\
\hline 2 & 3 & 4 & 5 \\
\hline 2 & 3 & 4 & 5 \\
\hline 2 & 3 & 4 & 5 \\
\hline 2 & 3 & 4 & 5 \\
\hline 2 & 3 & 4 & 5 \\
\hline 2 & 3 & 4 & 5 \\
\hline
\end{tabular}

\begin{tabular}{|c|c|c|c|}
\hline \multicolumn{4}{|c|}{$\begin{array}{l}\text { Rating Scale } \\
\text { e academic self- } \\
\text { veral important } \\
\text { these judgments on } \\
\text { ear similar, but each } \\
\text { or reference to } \\
\text { believe is the best } \\
\text { best not to debate or } \\
\text { ur minutes. }\end{array}$} \\
\hline \multicolumn{4}{|c|}{ Date: } \\
\hline Seldom & Sometimes & Usually & Alwa) \\
\hline 2 & 3 & 4 & 5 \\
\hline 2 & 3 & 4 & 5 \\
\hline 2 & 3 & 4 & 5 \\
\hline 2 & 3 & 4 & 5 \\
\hline 2 & 3 & 4 & 5 \\
\hline 2 & 3 & 4 & 5 \\
\hline 2 & 3 & 4 & 5 \\
\hline
\end{tabular}




\section{Appendix D}

10. This child takes criticism or corrections in strides without overreacting.

11. This child takes criticism or corrections in stride without overacting.

12. This child's company is sought by peers.

13. This child acts as a leader in group situations with peers.

14. This child refers to himself or herself in generally positive terms.

15. This child readily expresses opinions.

16. This child appreciates her or her work, work products, and activities.

$\begin{array}{lllll}1 & 2 & 3 & 4 & 5 \\ 1 & 2 & 3 & 4 & 5 \\ 1 & 2 & 3 & 4 & 5 \\ 1 & 2 & 3 & 4 & 5 \\ 1 & 2 & 3 & 4 & 5 \\ 1 & 2 & 3 & 4 & 5 \\ 1 & 2 & 3 & 4 & 5\end{array}$


Appendix E

Table 1

Correlations and Descriptive Statistics of Parental Overprotection, Teacher Closeness Aggregate, and Child Academic Self-esteem

\begin{tabular}{lccccc}
\hline Variables & $\mathrm{M}$ & SD & 1 & 2 & 3 \\
\hline 1. Parental Overprotection & 2.31 & .51 & - & & \\
2. Teacher Closeness Aggregate & 4.40 & .67 & -.30 & - & \\
3. Child Academic Self-esteem & 3.78 & .69 & $-.38^{*}$ & $.70^{* *}$ & - \\
\hline
\end{tabular}

Note. Maximum score for Parental Overprotection, Teacher Closeness Aggregate, and Child Academic Self-esteem was 5.

$* p<.05 . * * p<.01 . * * * p<.001$.

Table 2

Regression Analysis Summary for Parental Overprotection, Teacher Closeness Aggregate, and Child Academic Self-esteem

Child Academic Self-esteem

\begin{tabular}{lccc}
\hline Variable & $\mathrm{R}^{2}$ & $\Delta \mathrm{R}^{2}$ & $\beta$ \\
1. Parental Overprotection & .15 & .15 & $-.38^{*}$ \\
2. Teacher Closeness Aggregate & .51 & .36 & $.63^{*}$ \\
3. Parental Overprotection x Teacher & .51 & .00 & -.04 \\
$\quad$ Closeness Aggregate & & & \\
\hline
\end{tabular}

$* p<.05 . * * p<.01 . * * * p<.001$. 